DOI: https://doi.org/10.24127/ajpm.v9i2.2783

\title{
EFEKTIFITAS PENGGUNAAN MEDIA EDUTAINMENT DI TENGAH PANDEMI COVID-19
}

\author{
Loviga Denny Pratama ${ }^{1}$, Wahyu Lestari ${ }^{2}$, Ika Astutik ${ }^{3}$ \\ ${ }^{1,2,3}$ Universitas Islam Zainul Hasan, Probolinggo, Indonesia \\ E-mail: $\quad \frac{\text { loviga.pratama@gmail.com }}{\text { why.lestari93@gmail.com }}{ }^{2)}$
}

Received 28 April 2020; Received in revised form 21 June 2020; Accepted 26 June 2020

\begin{abstract}
Abstrak
Pada bulan Maret 2020 Presiden Indonesia dan berdasar Surat Edaran Kemendikbud Nomor 4 Tahun 2020 memandatkan untuk siswa belajar dari rumah akibat dari pandemi Covid-19. Adapun studi ini bertujuan untuk menguji keefektifan penggunaan media edutainment saat belajar dari rumah mulai diberlakukan akibat dari Covid-19. Data dianalisis menggunakan metode kuantitatif dan kualitatif. Adapaun data didapatkan menggunakan suatu instrumen tes dan non tes yang dapat diakses secara online. Sebanyak 2 jenis angket yang digunakan pada penelitian ini, yakni angket guru dan angket siswa. Sampel penelitian terdiri dari 232 siswa $(M=15$ tahun; $S D=0,5$ tahun) serta 32 guru matematika $(M=34$ tahun; $\mathrm{SD}=0,4$ tahun). Hasil studi menunjukkan bahwa mayoritas siswa dan guru memiliki persepsi yang positif untuk menggunakan media edutainment (pada fase kuesioner). Selain itu melalui media edutainment pada pembelajaran via daring, pencapaian aspek kognitif siswa (pada fase tes) juga memperoleh hasil yang positif. Sehingga hasil secara keseluruhan menunjukkan bahwa media edutainment efektif dalam menemani siswa belajar dari rumah.
\end{abstract}

Kata kunci: Game edukasi; media pembelajaran edutainment; pandemi Covid-19.

\begin{abstract}
In March 2020, President of Indonesia and based on the Ministry of Education and Culture Circular Letter 4 of 2020 mandated for students to learn from home as a result of the Covid-19 pandemic. The study aims to test the effectiveness of the use of media edutainment while learning from home began to apply as a result of Covid-19. Data is analyzed using quantitative and qualitative methods. The data is obtained using a test and non-test instrument that can be accessed online. A total of 2 types of questionnaires were used in this study, namely the teacher questionnaire and student questionnaire. The research sample consisted of 232 students $(M=15$ years; $S D=0.5$ years $)$ and 32 mathematics teachers $(M=34$ years; $S D=0.4$ years $)$. The results of the study show that the majority of students and teachers have a positive perception in using edutainment media (questionnaire phase). In addition, through the media edutainment,, students of achievement (in the test phase) has also gained positive results. So the overall results show that the media edutainment is effective in accompanying students learning from home.
\end{abstract}

Keywords: Covid-19 pandemic; educational game; edutainment instructional media.

\section{PENDAHULUAN}

Di Industri 4.0 ini, teknologi sangat penting dalam pengajaran dan pembelajaran matematika. Hadirnya teknologi dalam sebuah pembelajaran, dapat mempengaruhi variasi dalam hal pengajaran matematika ke siswa (Pratama \& Setyaningrum, 2018a). Teknologi ini juga mendukung dalam hal pengetahuan dalam fase abstrak, serta nilai kegunaan dalam fase konkret dari pembelajaran matematika. Namun, disisi lain pengintegrasian teknologi dalam pengajaran akan menjadi tantangan dalam dunia pendidikan di era ini (Mukminan, 2014). Oleh karenanya diperlukan pengetahuan secara meluas bagi stakeholder dunia 
pendidikan untuk memastikan penggunaan teknologi baru yang efektif (Mayes, Natividad, \& Spector, 2015).

Banyak cara untuk menerima tantangan di era Industri 4.0 ini. Salah satunya adalah dengan mengembangkan media edutainment (Pratama, Bahauddin, \& Lestari, 2019). Media pembelajaran ini memiliki unsur education (pendidikan) dan entertainment (hiburan). Media edutainment dapat dibedakan menjadi beberapa jenis, yakni seperti video, game komputer, musik, film, situs web, dan multimedia lainnya (Anikina \& Yakimenko, 2015). Di era ini, media edutainment ini menjadi sasaran bagi peneliti untuk meneliti implikasinya dalam dunia pendidikan. Salah satunya media ini dianggap sebagai alat untuk meningkatkan kualitas pengajaran dan pembelajaran (Mansour, Martin, Anderson, \& Gibson, 2017; Olive et al., 2010).

$\begin{array}{ccc}\text { Edutainment } & \text { berasal dari } \\ \text { kombinasi kata pendidikan dan }\end{array}$ hiburan. Karenanya pada media edutainment merupakan salah satu basis pembelajaran yang menggabungkan konten pendidikan ke dalam konteks hiburan untuk memfasilitasi pembelajaran (Singhal \& Rogers, 2013). Ada berbagai cara untuk melakukan pembelajaran berbasis media edutainment. Salah satunya dengan siswa belajar menggunakan layar komputer yang penuh dengan gambar dan desain warna-warni, sehingga meyakinkan pengguna bahwa belajar bisa dilakukan dengan menarik dan menghibur. Tentunya edutainment ini berbasis media instruksional menggunakan teknologi yang ada dengan hiburan modern sebagai media pembelajaran di kelas. Melalui belajar demikian, akan memberikan dampak positif pada proses pembelajaran dan memberikan pengalaman belajar yang menarik minat siswa (Pratama \& Setyaningrum, 2018b).

Ditengah maraknya pengintegrasian teknologi dalam pembelajaran, namun di beberapa kota kecil pengintegrasian ini masih belum menyeluruh. Bisa saja media pembelajaran edutainment menjadi kurang populer dalam pendidikan. Hal ini dipengaruhi oleh beberapa faktor diantaranya media ini dapat mengeluarkan biaya yang lebih tinggi (Mat Zin \& Mohd Zain, 2010). Namun faktanya di era ini terdapat teknologi yang ketersediannya terus meningkat, yakni perangkat mobile (starcell). Secara bertahap pembelajaran menggunakan perangkat mobile mulai populer diiringi oleh meningkatnya ketersediaan dengan nirkabel berbiaya rendah. Perangkat ini mulai dilirik oleh stakeholder dunia pendikan karena dalam fasilitasnya dapat mengoperasikan game, video, musik, dan lain sebagainya. Meskipun telah terdapat beberapa aplikasi media yang mendukung pengintegrasian teknologi dalam sebuah pembelajaran, namun masih belum dimanfaatkan sepenuhnya oleh guru matematika dalam proses pembelajaran. Bahkan siswa cenderung menggunakan media teknologi seperti smartphone hanya sebagai hiburan dan sarana berinteraksi sosial (Mohammad, Fayyoumi, \& Al-Shathry, 2015). Padahal perangkat seperti smartphone memiliki keunggulan penting yakni sangat accessible untuk digunakan kapan saja dan dimana saja.

$$
\text { Barulah ketika Presiden }
$$

Indonesia dan berdasar Surat Edaran Kemendikbud Nomor 4 Tahun 2020 yang memandatkan untuk siswa belajar dari rumah (via daring) akibat dari pandemi Covid-19, penggunaan 
perangkat smartphone maupun teknologi lain sebagai media untuk belajar semakin marak digunakan. Namun kondisi ini akan semakin menyusahkan ketika guru atau siswa dengan tingkat pemahaman teknologinya masih rendah. Oleh karena itu, artikel ini membahas tentang persepsi guru dan siswa tentang penggunaan media edutainment yang notabene sangat diperlukan dalam situasi pandemi ini. Persepsi ini dipandang penting karena dalam memahami siswa dapat membantu para guru dalam mengintegrasikan media edutainment ini. Selain persepsi ini juga dapat membantu para praktisi pendidikan untuk meningkatkan dan mengembangkan kualitas suatu aplikasi atau perangkat yang mendukung pembelajaran di tengah pandemi Covid-19 ini. Sehingga studi ini bertujuan untuk menguji keefektifan penggunaan media edutainment saat belajar dari rumah mulai diberlakukan akibat dari Covid-19.

\section{METODE PENELITIAN}

Data pada penelitian ini dianalisis menggunakan metode kuantitatif dan kualitatif. Adapun guru dan siswa sebagai partisipan dalam penelitian ini yang berafiliasi sekolah di Probolinggo. Metode pemilihan partisipan menggunakan metode sampling, dengan memilih secara acak satu guru dan empat siswa di setiap sekolah jenjang SMP/MTs di Probolinggo. Sehingga diperoleh sampel 232 siswa (119 pria dan 113 wanita) serta 32 guru matematika (17 pria dan 15 wanita) yang berpartisipasi dalam penelitian ini. Guru ( $\mathrm{M}=34$ tahun; $\mathrm{SD}=0,4$ tahun) adalah guru matematika yang telah memiliki pengalaman mengajar diberbagai tingkat unit pendidikan serta dengan durasi pengajaran yang berbeda.

Terdapat tiga fase dalam studi ini. Pertama, fase kuesioner dimana untuk mendeskripsikan berkaitan dengan persepsi guru dan siswa tentang penggunaan media edutainment di tengah pandemi Covid-19. Kedua, fase tes dimana akan menguji keefektifan dari suatu media edutainment ditinjau dari aspek kognitif siswa.

Fase kuesioner, menggunakan seluruh pertisipan yang dijelaskan sebelumnya untuk mengumpulkan data. Adapun untuk instrumen yang digunakan pada fase ini yakni angket yang dapat diakses secara online. Angket ini dibagi menjadi dua yakni angket persepsi guru dan persepsi siswa. Angket siswa berisi dua bagian. Bagian pertama terdiri dari lima pernyataan yang dibuka dan bagian kedua terdiri dari sepuluh pernyataan tertutup tentang persepsi siswa. Demikian juga pada angket guru yang berisi dua bagian. Bagian pertama terdiri dari sepuluh pertanyaan tertutup dan bagian kedua terdiri dari tujuh pertanyaan terbuka. Angket ini digunakan menggunakan skala Likert yang telah divalidasi konten oleh ahli.

Fase yang kedua yakni fase perlakuan (treatment). Fase ini hanya menggunakan siswa sebagai pertisipan. Dimana siswa belajar dengan terbagi menjadi dua kondisi (kelas kontrol dan kelas eksperimen) dalam belajar via daring. Kelas kontrol bagi mereka yang belajar via daring seperti biasanya, yakni guru memandu dalam mempelajari buku teksnya masingmasing melalui perangkat smartphone. Sedangkan kelas eksperimen bagi mereka yang belajar menggunakan media-media edutainment, yakni mengajar dengan menggunakan animasi, video pembelajaran, serta 
DOI: https://doi.org/10.24127/ajpm.v9i2.2783

bantuan aplikasi game edukasi seperti Proadventure (bisa unduh di Play Store)

Fase terakhir yakni fase tes, juga menggunakan siswa sebagai partisipan. Adapun instrumen yang digunakan pada fase ini adalah instrumen tes yang terbagi menjadi dua, yakni tes untuk mengukur kemampuan awal siswa (prior knowladge) dan post-test yang dilakukan setelah siswa menerima pembelajaran. Soal post-test terdiri dari dua tipe yakni tes numerik (maksimal skor 15) dan tes penalaran (maksimal skor 70). Adapun reliabilitas dari soal ini sebesar $\alpha=0.82$.

\section{HASIL DAN PEMBAHASAN}

Bagian ini akan menerangkan hasil penelitian mencakup tiga fase yang telah dilakukan. Berdasarkan tujuan tersebut, temuan penelitian akan dijelaskan sebagai berikut.

\section{Persepsi siswa tentang penggunaan media edutainment dalam pembelajaran matematika}

Bagian ini akan menceritakan hasil pengolahan data kuantitatif dan kualitatif dari angket siswa. Angket tersebut ditabulasi untuk mencatat respons dari masing-masing responden untuk setiap pilihan pertanyaan. Adapun data dari pertanyaan pertama berkaitan dengan penggunaan media edutainment di tengah pandemi Covid19 dapat dilihat pada Tabel 1. Hasil dari jawaban siswa didapatkan bahwa 96,6\% dari 232 siswa setuju bahwa belajar matematika di tengah pandemi Covid-19 ini membutuhkan elemen hiburan (entertainment). Hal ini menunjukkan bahwa hiburan dalam proses pembelajaran menjadi daya tarik utama pada siswa. Pernyataan ini diperkuat dengan adanya data jawaban siswa tentang pertanyaan mengenai
"Apakah media belajar yang menyisipkan hiburan didalamnya akan berdampak mengganggu konsentrasi belajar Anda?". Sebagian siswa sebanyak 4,78\% dari 232 siswa menjawab tidak setuju dalam pertanyaan tersebut. Hal ini sejalan dengan penelitian sebelumnya (Akhter \& Akhter, 2018) yang menjelaskan bahwa siswa memiliki persepsi yang kuat bahwa materi matematika yang diajarkan melalui media teknologi, akan membuat belajar lebih menarik. Selain itu, 60,26\% dari 232 siswa tidak setuju dengan pernyataan "meskipun menggunakan media yang menyisipkan hiburan, saya masih mengalami kesulitan dalam memahami materi matematika". Sehingga dari sudut pandang siswa, dapat disimpulkan bahwa pembelajaran edutainment sangat diperlukan dalam sebuah pembelajaran.

Tabel 1. Persepsi siswa terhadap media edutainment di tengah kondisi pandemi Covid-19.

Menurut Anda, haruskah ada unsur hiburan dalam proses pembelajaran matematika di tengah kondisi pandemi Covid-19 sekarang ini?

\begin{tabular}{ccccc}
\hline \multicolumn{2}{c}{ Harus } & & \multicolumn{2}{c}{ Tidak Harus } \\
\cline { 1 - 2 } \cline { 5 - 6 } $\mathbf{N}$ & Persentase & & N & Persentase \\
\hline 224 & 96,5 & & 8 & 3,5 \\
\hline
\end{tabular}

Perlunya elemen hiburan (entertainment) dalam belajar dapat disebabkan oleh berbagai hal. Hasil dalam Tabel 2 menunjukkan bahwa sebagian besar siswa beranggapan bahwa dengan mengimbuhkan suatu hiburan dalam belajar akan membuat proses pembelajaran tidak membosankan. Selain itu, siswa beranggapan bahwa dengan elemen hiburan dapat membuat mereka lebih memahami 
DOI: https://doi.org/10.24127/ajpm.v9i2.2783

matematika dan membuat proses belajar matematika lebih menyenangkan.

Tabel 2. Alasan siswa (5 alasan tertinggi) dalam memilih media belajar edutainment dalam proses pembelajaran.

Mengapa harus ada unsur hiburan (entertainment) dalam kegiatan pembelajaran?

\begin{tabular}{lcc}
\hline \multicolumn{1}{c}{ Argumen } & N & Persentase \\
\hline $\begin{array}{l}\text { Membantu } \\
\text { siswa dalam } \\
\text { memahami } \\
\text { materi }\end{array}$ & 33 & $14,2 \%$ \\
$\begin{array}{l}\text { Membuat situasi } \\
\text { belajar tidak } \\
\text { membosankan }\end{array}$ & & $60,8 \%$ \\
$\begin{array}{l}\text { Membuat siswa } \\
\text { lebih fokus } \\
\text { dalam belajar }\end{array}$ & & $7,8 \%$ \\
$\begin{array}{l}\text { Membuat siswa } \\
\text { lebih antusias } \\
\text { dalam belajar }\end{array}$ & 23 & $9,9 \%$ \\
$\begin{array}{l}\text { Membuat } \\
\text { kondisi belajar } \\
\text { kurang serius }\end{array}$ & 8 & $3,4 \%$ \\
\hline
\end{tabular}

Tabel 3. Media yang digunakan dalam belajar matematika

Jenis media apa yang digunakan oleh guru dalam proses pembelajaran matematika?

\begin{tabular}{ccc}
\hline Jenis Media & N & Persentase \\
\hline Buku & 132 & $56,9 \%$ \\
LKS & 57 & $24,6 \%$ \\
Slide & 24 & $10,3 \%$ \\
Presentasi & & \\
Alat Peraga & 11 & $4,7 \%$ \\
Game & 5 & $2,2 \%$ \\
Lainnya & 3 & $1,3 \%$ \\
\hline
\end{tabular}

Proses belajar matematika membosankan bagi siswa salah satu penyebabnya adalah karena media yang digunakan oleh guru kurang bervariasi.
Tabel 3 menunjukkan bahwa guru cenderung menggunakan buku $(56,9 \%)$ dalam proses pembelajaran, diikuti dengan penggunaan lembar kerja $(24,6 \%)$. Guru jarang menggunakan media edutainment dalam proses pembelajaran di tengah pandemi Covid-19 ini. Memang buku telah mendominasi sebagai media ajar yang digunakan oleh para guru, hal ini dikarenakan kemudahan memperolehnya dan ketersediaan buku yang ada tidak merepotkan untuk digunakan. Terlebih lagi penerapan Kurikulum 2013, pemerintah telah menyediakan buku tersendiri bagi guru dan siswa. Namun, tentunya buku ini bukan menjadi satu-satunya media untuk mengajarkan pelajaran ke siswa. Hal ini diperkuat dengan adanya penelitian sebelumnya (Aisyah, Chotimah, \& Meryansumayeka, 2019; Ngado, 2020) yang berhasil ketika mengajarkan matematika dengan menggunakan suatu media elektronik.

$\begin{array}{ccr}\text { Kurang } & \text { beragamnya media } \\ \text { pembelajaran } & \text { Matematika }\end{array}$
kurangnya unsur hiburan berdampak pada proses pembelajaran matematika di tengah pandemi Covid-19 ini. Sehingga membutuhkan media yang inovatif seperti media edutainment. Hal ini nampak ketika siswa antusias dalam menjawab pertanyaan tentang jenis hiburan yang dipilih untuk dimasukkan dalam media pembelajaran pada Tabel 4. Berdasarkan Tabel 4 diketahui $61,2 \%$ dari 232 siswa memilih game sebagai hiburan yang perlu dimasukkan ke dalam media pembelajaran di tengah kondisi pandemi Covid-19 ini. Namun hal ini tidak sejalan dengan apa yang siswa inginkan. Ketidakmampuan guru disebabkan oleh pengetahuan dan keterampilan serta asumsi bahwa dalam menggunakan media edutainment akan menimbulkan biaya yang lebih tinggi 
(Mat Zin \& Mohd Zain, 2010). Padahal akhir-akhir ini para peneliti telah mengembangkan berbagai media edutainment seperti media berbasis game edukasi dalam pembelajaran matematika (lihat, Aljojo, 2018; Widyasari, Sutopo, \& Agustian, 2019). Dan tak jarang juga ditemukan sebuah game edukasi menjadi media belajar yang dapat membantu siswa dalam meningkatkan hasil belajarnya (Setyaningrum, Pratama, \& Ali, 2018).

Tabel 4. Jenis hiburan.

Menurut Anda, manakah salah satu hiburan yang dipilih untuk dimasukkan ke dalam media pembelajaran?

\begin{tabular}{ccc}
\hline Jenis hiburan & N & Persentase \\
\hline Game & 142 & $61,2 \%$ \\
Komik & 40 & $17,2 \%$ \\
Video & 33 & $14,2 \%$ \\
Musik & 12 & $5,2 \%$ \\
Lainnya & 5 & $2,2 \%$ \\
\hline
\end{tabular}

Berdasarkan hasil angket siswa, dapat disimpulkan bahwa mayoritas siswa merespon positif bahkan perlu dilakukannya pembelajaran menggunakan media edutainment pada proses pembelajaran mereka dari rumah. Temuan ini menunjukkan bahwa dalam kondisi mereka belajar dari rumah, siswa ingin belajar sambil melepas kebosanan mereka. Oleh karena itu berdasarkan persepsi siswa, media edutainment khususnya dalam bentuk permainan (game) dapat menghilangkan kebosanan dalam proses belajar matematika.

\section{Persepsi guru tentang penggunaan media pengajaran Edutainment dalam pembelajaran Matematika}

Selain menjelaskan persepsi siswa tentang penggunaan media edutainment dalam pembelajaran matematika, penelitian ini juga akan menjelaskan bagaimana persepsi para guru. Sejauh ini para guru telah berusaha untuk memberikan nuansa yang menyenangkan untuk memfasilitasi belajar siswa di rumah, tetapi banyak guru juga mengatakan bahwa dengan perkembangan teknologi saat ini siswa menuntut inovasi baru dalam setiap pelajaran atau media yang digunakan. Terbukti berdasarkan penelitian terdahulu (Pratama \& Lestari, 2020) menyatakan bahwa pelatihan pembuatan media berbasis teknologilah yang banyak diminati oleh guru.

$\begin{array}{crr}\text { Pertanyaan } & \text { pertama dimulai } \\ \text { dengan seberapa } & \text { sering guru }\end{array}$ mengembangkan media untuk proses pembelajaran. Hasil analisis menunjukkan bahwa dari 32 guru, persentase guru tidak pernah mengembangkan media mencapai 34,4\%; guru yang terkadang membuat media pembelajaran mencapai $43,8 \%$; dan guru yang sangat sering membuat media mencapai 21,9\%. Meskipun hasil survei menunjukkan bahwa guru terkadang membuat media, tetapi media edutainment masih jarang dikembangkan oleh guru. Hal ini didukung oleh data tentang bagaimana pengalaman guru menggunakan media edutainment dalam mengajar matematika. Hasilnya bisa dilihat pada Gambar 1.

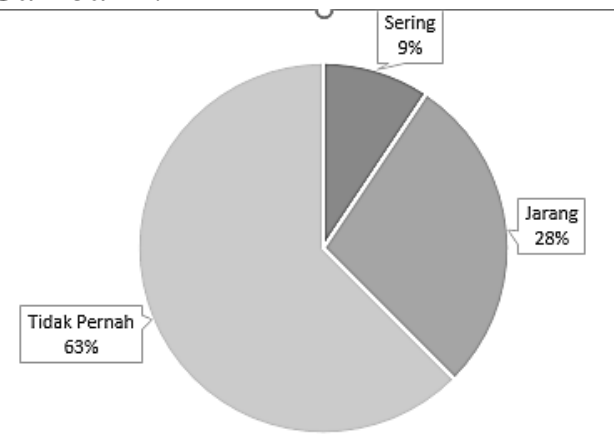

Gambar 1. Tingkat penggunaan media edutainment yang digunakan oleh guru. 
DOI: https://doi.org/10.24127/ajpm.v9i2.2783

Berdasarkan Gambar 1 menunjukkan dari 34 responden, terdapat $62,5 \%$ dari mereka menyatakan bahwa mereka tidak pernah menggunakan media edutainment dalam mengajar. Oleh karena itu hal ini tentu saja menjadi pertimbangan untuk mencari tahu mengapa guru tidak menggunakan media pembelajaran edutainment di saat pembelajaran diadakan dari rumah.

Setujukah Anda, perlu ada unsur hiburan (entertainment) ketika menggunakan suatu media pembelajaran?

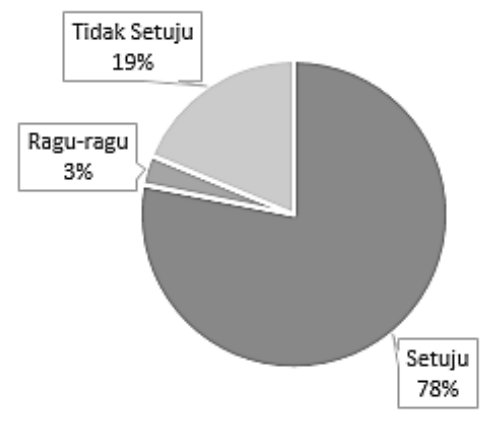

Gambar 2. Data perlunya elemen hiburan (entertainment).

Pertanyaan kedua diberikan kepada responden tentang perlunya elemen hiburan pada media pembelajaran yang digunakan. Hasilnya dapat dilihat pada Gambar 2. Ketika guru dihadapkan dengan opsi untuk menggunakan media edutainment dalam proses pembelajaran dari rumah, banyak guru yang memberikan kesan positif. Hasil analisis survei dalam Gambar 2 menunjukkan bahwa kebanyakan guru memiliki persepsi positif terhadap media pembelajaran berisi elemen hiburan seperti permainan, video, musik, komik, dan lain sebagainya.

Setelah memahami bahwa game yang paling diminati oleh siswa pada media edutainment, kemudian digali informasi tentang persepsi guru terhadap game yang tertuang pada media pembelajaran (lihat Gambar 3).

Setujukah Anda jika game edukasi dapat digunakan sebagai media belajar matematika?

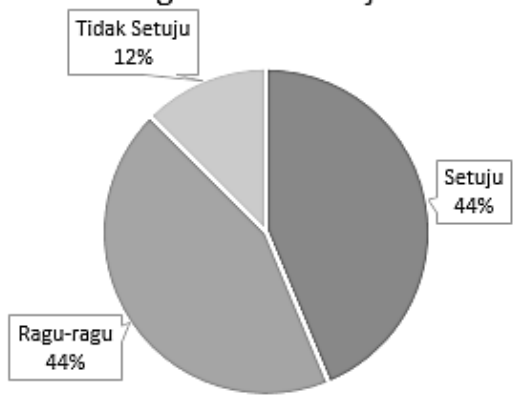

Gambar 3. Persepsi guru tentang game edukasi sebagai media untuk belajar.

Gambar 3 menunjukkan bahwa beberapa guru tidak setuju dengan adanya game edukasi sebagai media pembelajaran. Namun dalam keadaan lain ditunjukkan bahwa guru yang setuju dan ragu memiliki persentase yang sama. Hal ini menunjukkan bahwa guru tidak yakin dengan penggunaan game edukasi. Sebagian guru menyadari bahwa dengan pendekatan game dapat memberikan pengalaman belajar kepada siswa dengan berbagai animasi yang menarik. Tapi mereka menghadapi masalah dalam kaitannya dengan aksesibilitas terhadap sumber daya ICT dan kurangnya kesempatan pelatihan latihan-pelayanan (Chaamwe \& Shumba, 2016).

Berdasarkan hasil dari angket guru ini, menjelaskan bahwa sebagian besar guru memiliki persepsi positif tentang penggunaan media belajar edutainment terutama di tengah situasi pandemi Covid-19 ini. Namun demikian, ada beberapa guru yang tetap ragu dalam penggunaan media edutainment jika digunakan dalam proses belajar. Adapun aspek keraguan guru kami simpulkan sebagai berikut: 
DOI: https://doi.org/10.24127/ajpm.v9i2.2783

(1) media edutainment seperti game dikhawatirkan memiliki dampak negatif bagi siswa selama proses belajar; (2) Media edutainment seperti permainan dapat membuat siswa tidak fokus pada unsur pendidikan bahkan lebih fokus pada elemen hiburan; (3) Game berbasis media edutainment dapat menghambat proses pembelajaran, karena menggunakan fasilitas pendukung dalam bentuk perangkat elektronik; (4) game berbasis media edutainment ditakuti dapat membuat siswa sulit untuk memahami materi pengajaran yang diperlukan.

\section{Keefektifan Media Edutainment Ditinjau dari Aspek Kognitif Siswa}

Hasil dari fase ini akan dianalisis menggunakan aplikasi SPPS dengan menggunakan ANOVA. Berdasarkan Tabel 5 berkaitan dengan prior knowladge siswa, tidak ada perbedaan yang signifikan antara kelas kontrol dan kelas eksperimen (F (1109) $=2,23, \mathrm{p}>0,05 ; \mathrm{M}=56,88$ dan $\mathrm{M}=$ 56,$45 ; \mathrm{SD}=24,39$ dan $\mathrm{SD}=26,36$, untuk kelas kontrol dan eksperimen). Hasil ini menunjukkan bahwa kondisi awal dari kedua kelompok untuk pengetahuan sebelumnya adalah sama.

Tabel 5. Hasil dari fase tes.

\begin{tabular}{lccc}
\hline \multicolumn{1}{c}{ Jenis Tes } & $\begin{array}{c}\text { Pengukuran } \\
\text { Tes }\end{array}$ & $\begin{array}{c}\text { Pembelajaran Daring } \\
\text { Tanpa Media } \\
\text { Edutainment }\end{array}$ & $\begin{array}{c}\text { Pembelajaran Daring } \\
\text { Menggunakan Media } \\
\text { Edutainment }\end{array}$ \\
\cline { 3 - 4 } & & $\begin{array}{c}\text { Kelas Kontrol } \\
\text { N= 116 }\end{array}$ & $\begin{array}{c}\text { Kelas Eksperimen } \\
\text { N = 116 }\end{array}$ \\
\hline Prior & M & 71.22 & 70.77 \\
Knowledge & SD & 23.84 & 25.25 \\
Post-test & Numerik & & \\
& M & 9.52 & 14.39 \\
& SD & 4.23 & 4.34 \\
& Penalaran & & 67.83 \\
& M & 58.37 & 13.23 \\
& SD & 12.13 & 82.22 \\
& Total & 67.89 & 17,57 \\
\hline
\end{tabular}

Selanjutnya hasil analisis post test, menunjukkan bahwa terdapat efek yang signifikan dalam perlakuan kedua kelas kontrol dan eksperimen (F $(2,108)=4,42 ; \mathrm{p}<0,05)$. Namun, tidak ada efek yang signifikan antara perlakuan kedua kelas dengan prior knowladge $(\mathrm{F}(2108)=1,27 ; \mathrm{p}>0,05)$. Hasil menunjukkan bahwa terdapat perbedaan efektifitas antara pembelajaran daring seperti biasanya dengan pembelajaran daring menggunakan media edutainment. Seperti yang dapat dilihat dari Tabel 5, interaksi itu disebabkan oleh selisih skor yang dihasilkan siswa antara kelas kontrol dan kelas eksperimen pada tes numerik (selisih $=4,87$ ) dan uji penalaran (selisih $=9,46$ ). Lebih lanjut, pada analisis hasil post test ini dapat diketahui bahwa pembelajaran menggunakan media edutainment ini juga dapat meningkatkan kemampuan siswa dalam keahlian numerik dan penalaran. Hasil ini sesuai dengan penelitian sebelumnya yang melaporkan bahwa intervensi media edutainment dapat efektif dalam 
mengurangi kesenjangan dalam prestasi, khususnya keterampilan numerik (Dubé \& Keenan, 2016) dan penalaran matematis (McFeetors \& Palfy, 2017).

Hasil keseluruhan penelitian ini menandakan bahwa media edutainment sangat memfasilitasi siswa untuk belajar dari rumah. Meskipun pembelajaran dilakukan via daring sekalipun, pencapaian hasil belajar mereka lebih tinggi dibandingkan pembelajaran menggunakan buku seperti pembelajaran secara umumnya. Hasil ini sesuai dengan temuan sebelumnya (Hastuti et al., 2019; Mon, Meng Yap, \& Ahmad, 2019), yang telah mengindikasikan bahwa media edutainment memiliki sejumlah keunggulan untuk lingkungan belajar. Salah satunya integrasi muatan hiburan pada media edutainment, yang bertujuan untuk menciptakan iklim pembelajaran yang menyenangkan tanpa mengesampingkan materi yang harus dipelajari siswa (Barzilai \& Blau, 2014). Hal ini terlihat dalam penelitian ini, dimana siswa tidak hanya menyukai proses pembelajaran menggunakan media edutainment (melalui fase kuesioner) namun pencapain kognitif mereka (melalui fase tes) juga memperoleh hasil yang positif.

\section{KESIMPULAN DAN SARAN}

Hasil yang didapatkan dari penelitian ini menunjukkan bahwa mayoritas persepsi siswa dan guuru mendapat respon yang positif tentang penggunaan media edutainment disaat pembelajaran dari rumah mulai diberlakukan. Dari sisi persepsi guru, sebagian besar guru matematika dalam studi ini memiliki persepsi positif tentang penggunaan media edutainment terutama game edukasi dalam proses belajar matematika di tengah pandemi Covid-19 ini. Meskipun mayoritas guru tidak menggunakan media edutainment dalam proses pengajaran, mereka percaya bahwa media edutainment dalam bentuk game edukasi dapat meningkatkan kualitas pembelajaran dan meningkatkan minat siswa dalam belajar matematika di rumah. Hal itu terbukti pada fase tes dimana siswa yang belajar menggunakan media edutainment memperoleh hasil yang positif dalam aspek kognitif.

Meskipun penelitian ini hanya melibatkan sejumlah kecil siswa dan guru di satu distrik, serta ada beberapa aspek yang meragukan penggunaan media edutainment sebagai media belajar matematika, guru perlu mempertimbangkan penggunaan teknologi sebagai pembelajaran. Oleh karena itu, penelitian lebih lanjut diperlukan pada keempat aspek ini, jika aspek keraguan dapat diatasi, media pembelajaran edutainment menjadi media pembelajaran paling efektif yang digunakan dalam proses pembelajaran matematika.

\section{DAFTAR PUSTAKA}

Aisyah, N., Chotimah, U., \& Meryansumayeka. (2019). Developing e-learning content based on character values in mathematics teaching and learning. Journal of Physics: Conference Series, 1166(1). https://doi.org/10.1088/17426596/1166/1/012016

Akhter, N., \& Akhter, N. (2018). Learning in Mathematics : Difficulties and Perceptions of Students. Journal of Educational Research, 21(1), 147-163. Retrieved from https://www.researchgate.net/publ ication/328772457_Learning_in_ 
Mathematics_Difficulties_and_Pe rceptions_of_Students

Aljojo, N. (2018). The design and implementation of a mathematics game-base learning application for primary students. International Journal of Interactive Mobile Technologies, 12(3), 142-152. https://doi.org/10.3991/ijim.v12i3. 8739

Anikina, O. V., \& Yakimenko, E. V. (2015). Edutainment as a Modern Technology of Education. Procedia - Social and Behavioral Sciences, 166, 475-479. https://doi.org/10.1016/j.sbspro.20 14.12.558

Barzilai, S., \& Blau, I. (2014). Scaffolding game-based learning: Impact on learning achievements, perceived learning, and game experiences. Computers \& Education, 70(JANUARY 2014), 65-79.

https://doi.org/10.1016/j.compedu. 2013.08.003

Chaamwe, N., \& Shumba, L. (2016). Spreadsheets: A Tool for eLearning - A Case of Matrices in Microsoft Excel. International Journal of Information and Education Technology, 6(7), 570 575.

https://doi.org/10.7763/ijiet.2016. v6.753

Dubé, A. K., \& Keenan, A. (2016). Are games a viable home numeracy practice? In Early Childhood Mathematics Skill Development in the Home Environment (pp. 165184). https://doi.org/10.1007/9783-319-43974-7_10

Hastuti, Sadat, A., Nazar, A., Suherman, L. O. A., Alzarliani, W. O. D., Sapar, \& Birawida, A. B. (2019). Environmental care behavior through e-jas model with science edutainment approach. IOP Conference Series: Earth and Environmental Science, 343(1). https://doi.org/10.1088/1755-

1315/343/1/012126

Mansour, M., Martin, A. J., Anderson, M., \& Gibson, R. (2017). Getting into flow in the arts classroom: Research findings and implications for practice. Educational Practice and Theory, 39(2), 5-15. https://doi.org/10.7459/ept/39.2.02

Mat Zin, H., \& Mohd Zain, N. Z. (2010). the Effects of Edutainment Towards Students' Achievements. Regional Conference on Knowledge Integration in ICT 2010, 129, 2865. Retrieved from http://scholar.google.com/scholar? $\mathrm{hl}=\mathrm{en} \& b \operatorname{tnG}=$ Search\&q=intitle:N o+title\#0

Mayes, R., Natividad, G., \& Spector, J. (2015). Challenges for Educational Technologists in the 21st Century. Education Sciences, 5(3), 221-237. https://doi.org/10.3390/educsci503 0221

McFeetors, P. J., \& Palfy, K. (2017). We're in Math Class Playing Games, Not Playing Games in Math Class. Mathematics Teaching in the Middle School, 22(9), 534-544.

Mohammad, H., Fayyoumi, A., \& AlShathry, O. (2015). Do we have to prohibit the use of mobile phones in classrooms? International Journal of Interactive Mobile Technologies, 9(2), 54-57. https://doi.org/10.3991/ijim.v9i2.4 394

Mon, C. S., Meng Yap, K., \& Ahmad, A. (2019). A preliminary study on requirements of olfactory, haptic and audio enabled application for 
DOI: https://doi.org/10.24127/ajpm.v9i2.2783

visually impaired in edutainment. ISCAIE 2019 - 2019 IEEE Symposium on Computer Applications and Industrial Electronics, 249-253. https://doi.org/10.1109/ISCAIE.20 19.8743738

Mukminan. (2014). Tantangan Pendidikan di Abad 21. Teknologi Pendidikan, pp. 0-10.

Ngado, K. (2020). Optimalisasi Motivasi Dan Prestasi Belajar Siswa Menggunakan Moodle Berbantuan Computer Algebra System (Cas). AKSIOMA: Jurnal Program Studi Pendidikan Matematika, 9(1). https://doi.org/10.24127/ajpm.v9i 1.2657

Olive, J., Makar, K., Hoyos, V., Kor, L. K., Kosheleva, O., \& Sträßer, R. (2010). Mathematical Knowledge and Practices Resulting from Access to Digital Technologies. In New ICMI Study Series (Vol. 13, pp. 133-177). https://doi.org/10.1007/978-14419-0146-0_8

Pratama, L., \& Setyaningrum, W. (2018a). GBL in Math Problem Solving: Is it Effective? International Journal of Interactive Mobile Technologies (iJIM), 12(6), 101. https://doi.org/10.3991/ijim.v12i6. 8658

Pratama, L. D., Bahauddin, A., \& Lestari, W. (2019). Game Edukasi: apakah membuat belajar lebih menarik? At- Ta'lim, 5(1), 39-50.

Pratama, L. D., \& Lestari, W. (2020). Pengaruh Pelatihan Terhadap Kompetensi Pedagogik. Jurnal Cendekia: Jurnal Pendidikan Matematika, 4(1), 278-285.
Pratama, L. D., \& Setyaningrum, W. (2018b). Game-Based Learning: The effects on student cognitive and affective aspects. Journal of Physics: Conference Series, 1097(1).

https://doi.org/10.1088/17426596/1097/1/012123

Setyaningrum, W., Pratama, L. D., \& Ali, M. B. (2018). Game-Based Learning in Problem Solving Method: The Effects on Students' Achievement. International Journal on Emerging Mathematics Education, 2(2), 157. https://doi.org/10.12928/ijeme.v2i 2.10564

Singhal, A., \& Rogers, E. M. (2013). The Entertainment-Education Strategy in Communication Campaigns. In Public Communication Campaigns (pp. 343-356).

https://doi.org/10.4135/978145223 3260.n28

Widyasari, W., Sutopo, H., \& Agustian, M. (2019). QR codebased learning development: Accessing math game for children learning enhancement. International Journal of Interactive Mobile Technologies, 13(11), 111-124. https://doi.org/10.3991/ijim.v13i1 1.10976 